\title{
Convenient Synthesis of a Novel Flavonoid with Extended $\pi$-System: Active Agent for UVA Protection
}

\author{
Saleh Al-Busafi \\ Department of Chemistry, College of Science, Sultan Qaboos University, P.O. Box 36, Al-Khodh 123, Oman \\ Correspondence should be addressed to Saleh Al-Busafi; saleh1@squ.edu.om
}

Received 9 October 2012; Accepted 1 December 2012

Academic Editor: Antreas Afantitis

Copyright (C) 2013 Saleh Al-Busafi. This is an open access article distributed under the Creative Commons Attribution License, which permits unrestricted use, distribution, and reproduction in any medium, provided the original work is properly cited.

Flavonoid derivative with extended cinnamic acid moiety was synthesized using Baker-Venkataraman reaction. The compound shows interesting UV absorption properties which make it a good UVA absorber. A bathochromic shift of $18 \mathrm{~nm}$ was observed when the size of cinnamic acid segment was increased by one styrylogous extension.

\section{Introduction}

Flavonoids play an important role in biological processes in plants and other biological species [1]. Human diet contains trace amount of flavonoids which have been reported to exhibit a wide range of biological activities. These biological properties include anti-inflammatory [2], antibacterial, antitumor [3], antioxidant [4], antiviral [5], antiallergenic [6], and protein kinase $\mathrm{C}$ inhibitors [7]. Besides, it is known that some flavonoids have antifeedant activity against some phytophagous and a subterranean termite (Coptotermes sp.) [8]. Recently, flavonoids were recommended for the treatment of allergic and inflammatory diseases [9].

In addition, flavonoids are known for their ability to act as UV-absorbers and radical quenching compounds [10, 11]. Because of this important property, flavonoids are exploited by plants to protect them from the sun UV radiation. This use could be utilized in the protection of human hair and skin from UV radiation. It is well known that exposure to UV radiation can damage skin and hair fibers $[12,13]$. UVB radiation is the principal radiation responsible for inducing skin cancer and hair protein loss (causing dryness, reduced strength, rough surface texture, and decreased luster) [14]. On the other hand, UVA radiation is responsible for premature photoaging of the skin and for color changes of hair [15]. Structurally, flavonoids can be divided into two main segments: the cinnamic acid subchromophore and the benzoyl subchromophore (Figure 1).
By altering the chromone substitution pattern, the UV absorption properties can be adjusted to individual needs. For example, a bathochromic shift was observed (from $294 \mathrm{~nm}$ to $330 \mathrm{~nm}$ ) when the size of the cinnamic acid fragment was increased by introducing one vinylogous extension in the $\pi$-system (Figure 2) [16]. This means that flavone 1 would protect better against UVB and thus against hair protein loss, whilst 2-styryl-4H-chromen-4-one 2 would protect better against UVA radiation and hair color changes.

On the other hand, introducing an electron donating group such as hydroxyl group to the benzoyl subchromophore caused a hypsochromic shift from $294 \mathrm{~nm}$ to $265 \mathrm{~nm}$ (Figure 3) which means that 5-hydroxyflavone 3 would protect better against UVC [13].

Several methods have been applied for the synthesis of flavonoids for example, Allan-Robinson strategy, cyclization of chalcones, and via an intramolecular Wittig reaction [17, 18]. One of the most common methods used to prepare flavonoids involves acylation of $o$-hydroxyacetophenone with an aromatic acid chloride yielding an aryl ester. The ester is then rearranged by a base (the Baker-Venkataraman reaction) to a 1,3-diaryl-1,3-diketone [19]. The later compound gives 2arylchromone (flavone) via acid-catalyzed cyclization. Here, we report the synthesis of a novel flavone derivative 4 in which the cinnamic acid fragment is increased by introducing a styryl extension in the $\pi$-system and to study its UV absorption properties. 


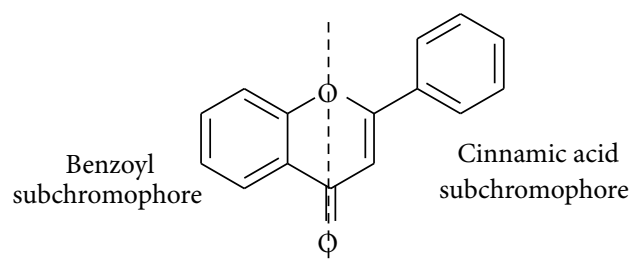

FIGURE 1: Benzoyl versus cinnamic acid subchromophores.

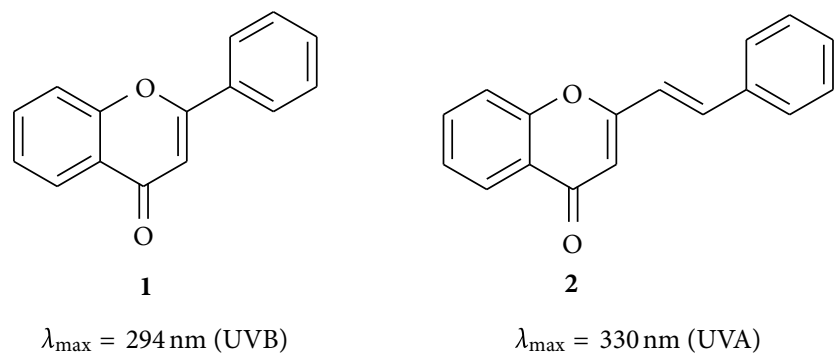

FIGURE 2: UV absorption of flavone and 2-styryl-4H-chromen-4one.

\section{Results and Discussion}

Our strategy to make compound $\mathbf{4}$ started from the phosphonium salt 5 which was prepared by the reaction of 4-(bromomethyl)benzoic acid with triphenylphosphine in acetone (Scheme 1). We envisaged that the double bond between the two phenyl groups in the target compound $\mathbf{4}$ can be constructed via Wittig reaction between a suitable phosphorus ylide and benzaldehyde. So, the reaction of the salt 5 with benzaldehyde in $\mathrm{H}_{2} \mathrm{O} / \mathrm{CH}_{2} \mathrm{Cl}_{2}$ system in the presence of $\mathrm{NaOH}$ yielded the alkene as a mixture of $Z$ and $E$-isomers which was isomerized to the $E$-isomer 6 by treatment of the product mixture with a trace of iodine. The conversion of $\mathbf{6}$ into the acid chloride 7 was afforded using thionyl chloride following literature procedures [20]. The crude acid chloride 7 was subsequently reacted with 2hydroxyacetophenone in pyridine to give ester $\mathbf{8}$ in 50\% yield. Next, we turned our attention to construct the heterocyclic ring in the desired flavonoid derivative $\mathbf{4}$ using BakerVenkataraman rearrangement of ester $\mathbf{8}$. Thus, upon refluxing a pyridine solution of $\mathbf{8}$ in the presence of $\mathrm{KOH}$ followed by treatment with $\mathrm{H}_{2} \mathrm{SO}_{4}$ afforded successfully flavonoid derivative 4 in $63 \%$.

The UV absorption properties of compound $\mathbf{4}$ and flavone 1 were measured. A bathochromic shift was observed when the cinnamic acid fragment was extended by styryl group. The maximum absorption of flavonoid derivative 4 is at $312 \mathrm{~nm}$ (UVA) compared to $294 \mathrm{~nm}$ (UVB) for flavone 1 . We believe that flavonoid derivative 4 is much better UVA absorber than flavonoid derivative $\mathbf{2}$ since it absorbs at a wide UVA range.

\section{Experimental}

The reagents and solvent were obtained from Aldrich and used without further purification. UV-vis spectra were measured using a Shimadzu, Model UV-1650PC spectrophotometer and reported as $\lambda_{\max }$ in $\mathrm{nm}(\varepsilon)$. IR spectra were obtained with a Nicolet model Magna 560 spectrometer; absorption bands are recorded in wave number $\left(\mathrm{cm}^{-1}\right)$. NMR spectra were recorded on a Bruker Avance $400\left({ }^{1} \mathrm{H}\right.$ : $\left.400 \mathrm{MHz},{ }^{13} \mathrm{C}: 100.6 \mathrm{MHz}\right)$. The chemical shifts are in $\delta$ values $(\mathrm{ppm})$ relative to the internal standard TMS and reported as chemical shift (multiplicity, coupling constant, and number of protons, assignment). Mass spectra were measured using HPLC-MS.

3.1. Synthesis of E-4-Styrylbenzoic Acid 6. 4-Carboxybenzyltriphenylphosphonium bromide $\mathbf{5}(7.30 \mathrm{~g}, 15.3 \mathrm{mmol})$ was suspended in dichloromethane $(175 \mathrm{~mL})$ in an Erlenmeyer flask. $75 \mathrm{~mL}$ of aqueous solution of sodium hydroxide $(50 \mathrm{~g})$ and benzaldehyde $(2.0 \mathrm{~mL})$ were added to the reaction mixture. The neck of the flask was plugged with cotton wool and the yellow mixture stirred for 30 minutes. The organic layer was separated and the aqueous layer was extracted with $(2 \times 20 \mathrm{~mL})$ dichloromethane. The combined organic layer was dried over $\mathrm{MgSO}_{4}$, filtered, and concentrated under reduced pressure. Petroleum ether $(50 \mathrm{~mL})$ and few crystals of iodine were added to the residue and the mixture was refluxed for $3 \mathrm{~h}$. The reaction mixture was washed with $25 \%$ sodium metabisulfite and the organic layer was dried over $\mathrm{MgSO}_{4}$ and concentrated under reduced pressure to give a white solid. The solid was recrystallised from ethanol to yield white needles (7.39 g, $0.033 \mathrm{~mol}, 75 \%)$. Mp $105.1^{\circ} \mathrm{C}$; IR (KBr): $v_{\max }\left(\mathrm{cm}^{-1}\right)=3500-2496,3054,1714,1611,752 ;{ }^{1} \mathrm{H}$ NMR $\left(400 \mathrm{MHz}, \mathrm{CDCl}_{3}\right): \delta(\mathrm{ppm})=7.15(\mathrm{~d}, 1 \mathrm{H}, J=16.6 \mathrm{~Hz}, \mathrm{H}-$ $\left.2^{\prime}\right), 7.21\left(\mathrm{~m}, 1 \mathrm{H}, \mathrm{H}-6^{\prime}\right), 7.29\left(\mathrm{~d}, 1 \mathrm{H}, J=16.6 \mathrm{~Hz}, \mathrm{H}-1^{\prime}\right), 7.47$ $\left(\mathrm{m}, 2 \mathrm{H}, \mathrm{H}-5^{\prime}\right.$ and $\left.\mathrm{H}-7^{\prime}\right), 7.54(\mathrm{~d}, 2 \mathrm{H}, J=8.1 \mathrm{~Hz}, \mathrm{H}-3$ and $\mathrm{H}-$ 5), $7.67\left(\mathrm{~m}, 2 \mathrm{H}, \mathrm{H}-4{ }^{\prime}\right.$ and $\left.\mathrm{H}-8^{\prime}\right), 7.70(\mathrm{~d}, J=8.1 \mathrm{~Hz}, 2 \mathrm{H}, \mathrm{H}-2$ and $\mathrm{H}-6) ;{ }^{13} \mathrm{C}$ NMR $\left(100.6 \mathrm{MHz}, \mathrm{CDCl}_{3}\right): \delta(\mathrm{ppm})=124.4$ $\left(\mathrm{C}-2^{\prime}\right), 126.8\left(\mathrm{C}-1^{\prime}\right), 128.9(\mathrm{C}-3$ and $\mathrm{C}-5), 130.0\left(\mathrm{C}-4^{\prime}\right.$ and C-8' $), 130.8\left(\mathrm{C}-5^{\prime}\right.$ and $\left.\mathrm{C}-7^{\prime}\right), 131.9\left(\mathrm{C}-6^{\prime}\right), 132.9(\mathrm{C}-2$ and $\mathrm{C}-$ 6), $133.7(\mathrm{C}-1), 145.2\left(\mathrm{C}-3^{\prime}\right), 149.9(\mathrm{C}-4), 165.6(\mathrm{C}=\mathrm{O})$.

3.2. Synthesis of E-4-Styrylbenzoyl Chloride 7. A mixture of E-4-styrylbenzoic acid $6(3.57 \mathrm{~g}, 16.0 \mathrm{mmol})$ and thionyl chloride $(1.65 \mathrm{~mL}, 22.5 \mathrm{mmol})$ was heated under reflux for $1 \mathrm{~h}$. Excess thionyl chloride was removed under reduced pressure and the crude solid $(3.10 \mathrm{~g}, 12.8 \mathrm{mmol}, 80 \%)$ was used for the next step.

3.3. Synthesis of E-2-Acetylphenyl 4-Styrylbenzoate 8. To a solution of 2-hydroxyacetophenone $(1.25 \mathrm{~g}, 9.25 \mathrm{mmol})$ in pyridine $(2.3 \mathrm{~mL})$ was added $E$-4-styrylbenzoyl chloride $7(2.24 \mathrm{~g}, 9.25 \mathrm{mmol})$. The reaction mixture was stirred briefly at room temperature. The temperature of the reaction increased spontaneously. After cooling, the reaction mixture was poured into a mixture of $60 \mathrm{~mL} \mathrm{HCl} \mathrm{(3 \% )} \mathrm{and} 30 \mathrm{~g}$ crushed ice. The product was extracted with chloroform 


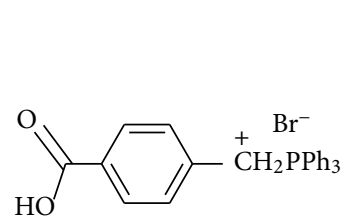

5
(1)<smiles>O=C(NCOCCOCCl)c1ccccc1</smiles>

(2) $\mathrm{I}_{2}, 75 \%$
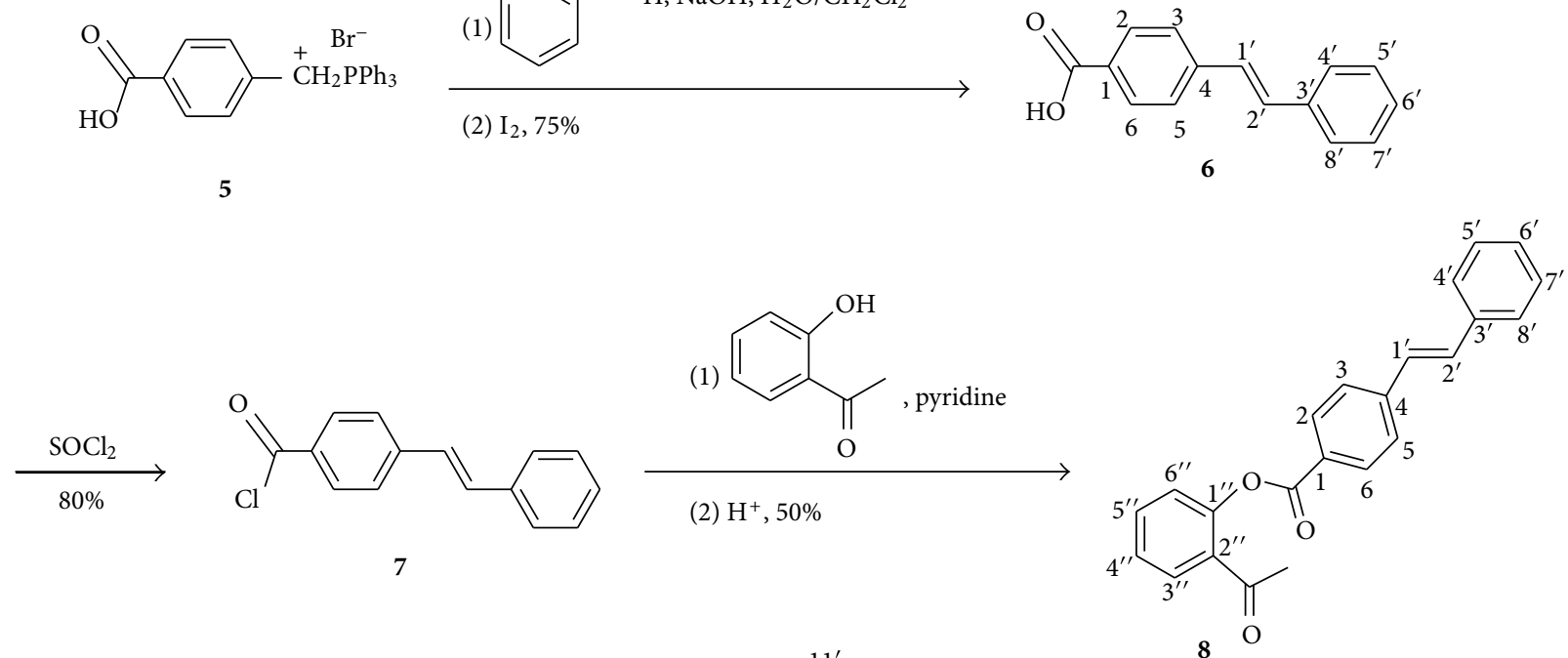

(1) Pyridine, $\mathrm{KOH}$

(2) $\mathrm{H}_{2} \mathrm{SO}_{4}$, reflux, $63 \%$<smiles>O=C(O)COCCCCCCCCCCCCC=Cc1ccc(-c2cc(=O)c3ccccc3o2)cc1</smiles>

Scheme 1: Synthesis of flavone derivative 4.<smiles>O=c1cc(-c2ccccc2)oc2ccccc12</smiles>

$\lambda_{\max }=294 \mathrm{~nm}(\mathrm{UVB})$

FIGURE 3: UV absorption of flavone and 5-hydroxyflavone.<smiles>O=c1cc(-c2ccc(/C=C/c3ccccc3)cc2)oc2ccccc12</smiles>

Figure 4
$(3 \times 10 \mathrm{~mL})$ and the combined organic layer was dried over $\mathrm{MgSO}_{4}$ and evaporated to give yellowish oil. The product was purified by column chromatography on silica gel eluting with hexane: ethyl acetate (9:1) (1.58 g, $4.63 \mathrm{mmol}, 50 \%)$. IR (Nujol oil): $v_{\max }\left(\mathrm{cm}^{-1}\right)=3031,2900,1715,1637,810 ;{ }^{1} \mathrm{H}$ NMR $\left(400 \mathrm{MHz}, \mathrm{CDCl}_{3}\right): \delta(\mathrm{ppm})=2.55\left(\mathrm{~s}, 3 \mathrm{H}, \mathrm{CH}_{3}\right), 7.23$ $\left(\mathrm{d}, 1 \mathrm{H}, J=15.8 \mathrm{~Hz}, \mathrm{H}-2^{\prime}\right), 7.26\left(\mathrm{~m}, 1 \mathrm{H}, \mathrm{H}-4^{\prime \prime}\right), 7.32(\mathrm{~d}, 2 \mathrm{H}$, $J=8.3 \mathrm{~Hz}, \mathrm{H}-3$ and $\mathrm{H}-5), 7.34\left(\mathrm{~m}, 1 \mathrm{H}, \mathrm{H}-6^{\prime \prime}\right), 7.36(\mathrm{~d}, 1 \mathrm{H}$, $\left.J=15.8 \mathrm{~Hz}, \mathrm{H}-1^{\prime}\right), 7.45$ (m, 3H, H-5', H-6', H-7'), 7.55 (m, $2 \mathrm{H}, \mathrm{H}-4^{\prime}$ and $\left.\mathrm{H}-8^{\prime}\right), 7.57$ (m, $\left.1 \mathrm{H}, \mathrm{H}-5^{\prime \prime}\right), 7.85\left(\mathrm{~m}, 1 \mathrm{H}, \mathrm{H}-3^{\prime \prime}\right)$, $8.10(\mathrm{~d}, 2 \mathrm{H}, J=8.3 \mathrm{~Hz}, \mathrm{H}-2$ and $\mathrm{H}-6) ;{ }^{13} \mathrm{C} \mathrm{NMR}(100.6 \mathrm{MHz}$, $\left.\mathrm{CDCl}_{3}\right): \delta(\mathrm{ppm})=30.3\left(\mathrm{CH}_{3}\right), 124.3\left(\mathrm{C}-6^{\prime \prime}\right), 126.4\left(\mathrm{C}-2^{\prime \prime}\right)$,
$126.5\left(\mathrm{C}-4^{\prime \prime}\right), 126.9\left(\mathrm{C}-1^{\prime}\right.$ and C-2'), 129.1 (C-1), 129.8 (C3,C-5,C-4',C-8'), 130.6 (C-6'), 130.7 (C-3'), 130.8 (C-2 and C-6), $130.9\left(\mathrm{C}-5^{\prime \prime}\right), 131.9\left(\mathrm{C}-3^{\prime \prime}\right), 133.7\left(\mathrm{C}-5^{\prime}\right.$ and $\left.\mathrm{C}-7^{\prime}\right), 145.2$ (C-4), 149.9 (C-1"), 165.6 (COO), 198.0 (CO).

3.4. Synthesis of Flavonoid Derivative 4. To a solution of E-2-acetylphenyl 4 -styrylbenzoate $8(0.25 \mathrm{~g}, 0.73 \mathrm{mmol})$ in pyridine $(0.85 \mathrm{~mL})$ at $50^{\circ} \mathrm{C}$ was added potassium hydroxide $(0.062 \mathrm{~g}, \mathrm{mmol})$ and the mixture was stirred for $15 \mathrm{~min}$. Acetic acid solution $(10 \%, 1.3 \mathrm{~mL})$ was added to the cooled mixture and the solid intermediate was collected by filtration (Figure 4). To a solution of the solid intermediate in acetic acid was added concentrated sulfuric acid $(0.03 \mathrm{~mL})$ and 
the mixture was refluxed for 1 hour. The cooled mixture was poured into ice and the product was collected by suction filtration and washed with water. The product was recrystallized from petroleum $(0.13 \mathrm{~g}, 63 \%)$. IR (Nujol oil): $v_{\max }\left(\mathrm{cm}^{-1}\right)=1706,1637,1577,1259 ; \lambda_{\max }(\mathrm{nm})(\log \varepsilon) 252$ (3.87), 288 (4.22), 312 (4.67), 455 (1.45); ${ }^{1} \mathrm{H}$ NMR (400 MHz, $\left.\mathrm{CDCl}_{3}\right): \delta(\mathrm{ppm})=6.82(\mathrm{~s}, 1 \mathrm{H}, \mathrm{H}-3), 7.28(\mathrm{~d}, 1 \mathrm{H}, J=13.6 \mathrm{~Hz}$, $\left.\mathrm{H}-7^{\prime}\right), 7.33\left(\mathrm{~d}, 2 \mathrm{H}, J=8.2 \mathrm{~Hz}, \mathrm{H}-2^{\prime}\right.$ and $\left.\mathrm{H}-6^{\prime}\right), 7.43(\mathrm{~m}, 4 \mathrm{H})$, 7.57 (m, 3H), 7.71 (m, 1H, H-7), 7.83 (d, 2H, J = 8.2 Hz, H$3^{\prime}$ and $\left.\mathrm{H}-5^{\prime}\right), 8.02\left(\mathrm{~d}, 1 \mathrm{H}, J=13.6 \mathrm{~Hz}, \mathrm{H}-8^{\prime}\right), 8.23(\mathrm{~m}, 1 \mathrm{H}$, $\mathrm{H}-5) ;{ }^{13} \mathrm{CNMR}\left(100.6 \mathrm{MHz}, \mathrm{CDCl}_{3}\right): \delta(\mathrm{ppm})=108.0(\mathrm{C}-$ 3), 118.5 (C-8), 124.4 (C-6), 125.6 (C-9), 125.7 (C-7', C-8' ), 126.2 (C-2', C-6' ), 126.7 (C-10', C-14'), 129.4 (C-1'), 129.5 (C-12'), 129.6 (C-3', C-5'), 130.2 (C-11', C-13'), 132.0 (C-5), 132.2 (C-4'), 134.2 (C-9'), 142.7 (C-7), 156.7 (C-10), 164.1 (C-2), 179.0 (C-4).

\section{Acknowledgments}

The author acknowledges, with thanks, financial support from the Sultan Qaboos University. The author is grateful to Mahmood Al Azwani, Department of Chemistry, Sultan Qaboos University, Oman, for the NMR spectra.

\section{References}

[1] A. Ghasemzadeh and N. Ghasemzadeh, "Flavonoids and phenolic acids: role and biochemical activity in plants and human," Journal of Medicinal Plants Research, vol. 5, no. 31, pp. 6697-6703, 2011.

[2] M.-H. Pan, C.-S. Laia, and C.-T. Ho, "Anti-inflammatory activity of natural dietary flavonoids," Food \& Function, vol. 1, pp. 15-31, 2010.

[3] G. W. Kabalka and A. R. Mereddy, "Microwave-assisted synthesis of functionalized flavones and chromones," Tetrahedron Letters, vol. 46, no. 37, pp. 6315-6317, 2005.

[4] M. Furusawa, T. Tanaka, T. Ito et al., "Antioxidant activity of hydroxyflavonoids," Journal of Health Science, vol. 51, no. 3, pp. 376-378, 2005.

[5] K. H. Miean and S. Mohamed, "Flavonoid (myricetin, quercetin, kaempferol, luteolin, and apigenin) content of edible tropical plants," Journal of Agricultural and Food Chemistry, vol. 49, no. 6, pp. 3106-3112, 2001.

[6] J. A. Seijas, M. P. Vázquez-Tato, and R. Carballido-Reboredo, "Solvent-free synthesis of functionalized flavones under microwave irradiation," Journal of Organic Chemistry, vol. 70, no. 7, pp. 2855-2858, 2005.

[7] A. O. Prykhod'ko, G. G. Dubinina, S. M. Golovach, and S. M. Yarmoluk, "Inhibitors of protein kinase CK2," Ukrainica Bioorganica Acta, vol. 1, no. 1-2, pp. 39-48, 2004.

[8] R. X. Shi, C. N. Ong, and H. M. Shen, "Protein kinase C inhibition and $\mathrm{X}$-linked inhibitor of apoptosis protein degradation contribute to the sensitization effect of luteolin on tumor necrosis factor-related apoptosis-inducing ligand-induced apoptosis in cancer cells," Cancer Research, vol. 65, no. 17, pp. 7815-7823, 2005.

[9] D. Kempuraj, B. Madhappan, S. Christodoulou et al., "Flavonols inhibit proinflammatory mediator release, intracellular calcium ion levels and protein kinase $\mathrm{C}$ theta phosphorylation in human mast cells," British Journal of Pharmacology, vol. 145, no. 7, pp. 934-944, 2005.

[10] M. Sisa, S. L. Bonnet, D. Ferreira, and J. H. Van Der Westhuizen, "Photochemistry of flavonoids," Molecules, vol. 15, no. 8, pp. 5196-5245, 2010.

[11] A. Kootstra, "Protection from UV-B-induced DNA damage by flavonoids," Plant Molecular Biology, vol. 26, no. 2, pp. 771-774, 1994.

[12] A. Chiu and A. B. Kimball, "Topical vitamins, minerals and botanical ingredients as modulators of environmental and chronological skin damage," British Journal of Dermatology, vol. 149, no. 4, pp. 681-691, 2003.

[13] B. Starcher, R. Pierce, and A. Hinek, "UVB irradiation stimulates deposition of new elastic fibers by modified epithelial cells surrounding the hair follicles and sebaceous glands in mice," Journal of Investigative Dermatology, vol. 112, no. 4, pp. 450-455, 1999.

[14] N. A. C. Santos and J. Inees, "Hair color changes and protein damage caused by ultraviolet radiation," Journal of Photochemistry and Photobiology B, vol. 74, no. 2-3, pp. 109-117, 2004.

[15] N. A. C. Santos, N. A. Kaoru, and J. Inees, "Impairment of hair mechanical properties by sun exposure and bleaching treatments," Journal of Cosmetic Science, vol. 55, no. 6, pp. 533-537, 2004.

[16] T. Jungblut, J. Schnitzler, W. Heller et al., "Die strukturen UV-Binduzierter sonnenschutzpigmente der kiefer (Pinus sylvestris L.)," Angewandte Chemie, vol. 107, no. 3, pp. 376-378, 1995.

[17] J. Staunton, "Gamm-pyrones and chromones," in Comprehensive Organic Chemistry. The Synthesis and Reactions of Organic Compounds, D. Barton and W. D. Ollis, Eds., vol. 4, Pergamon Press, Oxford, UK, 1979.

[18] A. K. Ganguly, S. Kaur, P. K. Mahata, D. Biswas, B. N. Pramanik, and T. M. Chan, "Synthesis and properties of 3-acyl- $\gamma$-pyrones, a novel class of flavones and chromones," Tetrahedron Letters, vol. 46, no. 23, pp. 4119-4121, 2005.

[19] R. S. Varma, R. K. Saini, and D. Kumar, "An expeditious synthesis of flavones on montmorillonite K 10 clay with microwaves," Journal of Chemical Research S, no. 6, pp. 348-349, 1998.

[20] T. S. Wheeler, "1-(2-hydroxyphenyl)-3-phenyl-1, 3-propanedione-chem synthesis," Organic Syntheses, vol. 4, p. 478, 1963. 

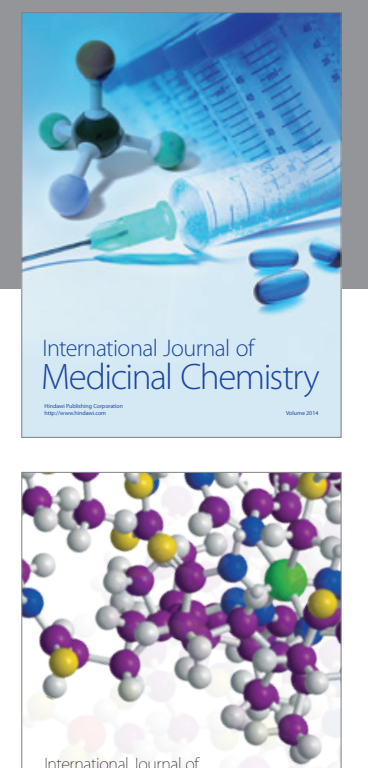

\section{Carbohydrate} Chemistry

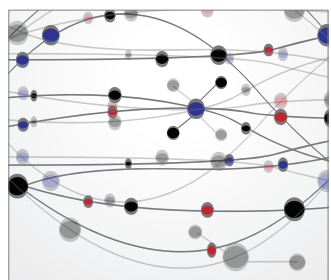

The Scientific World Journal
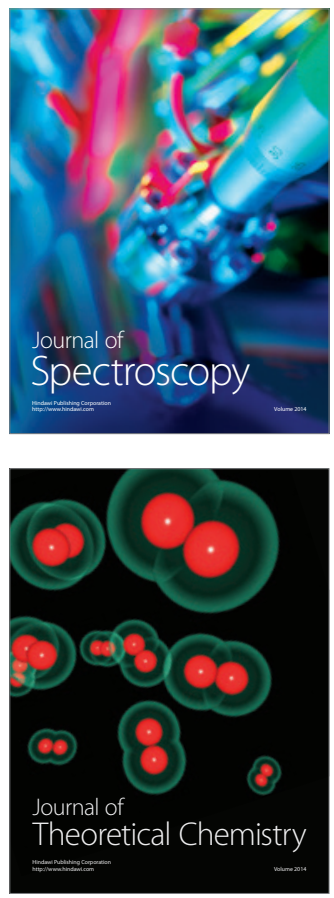
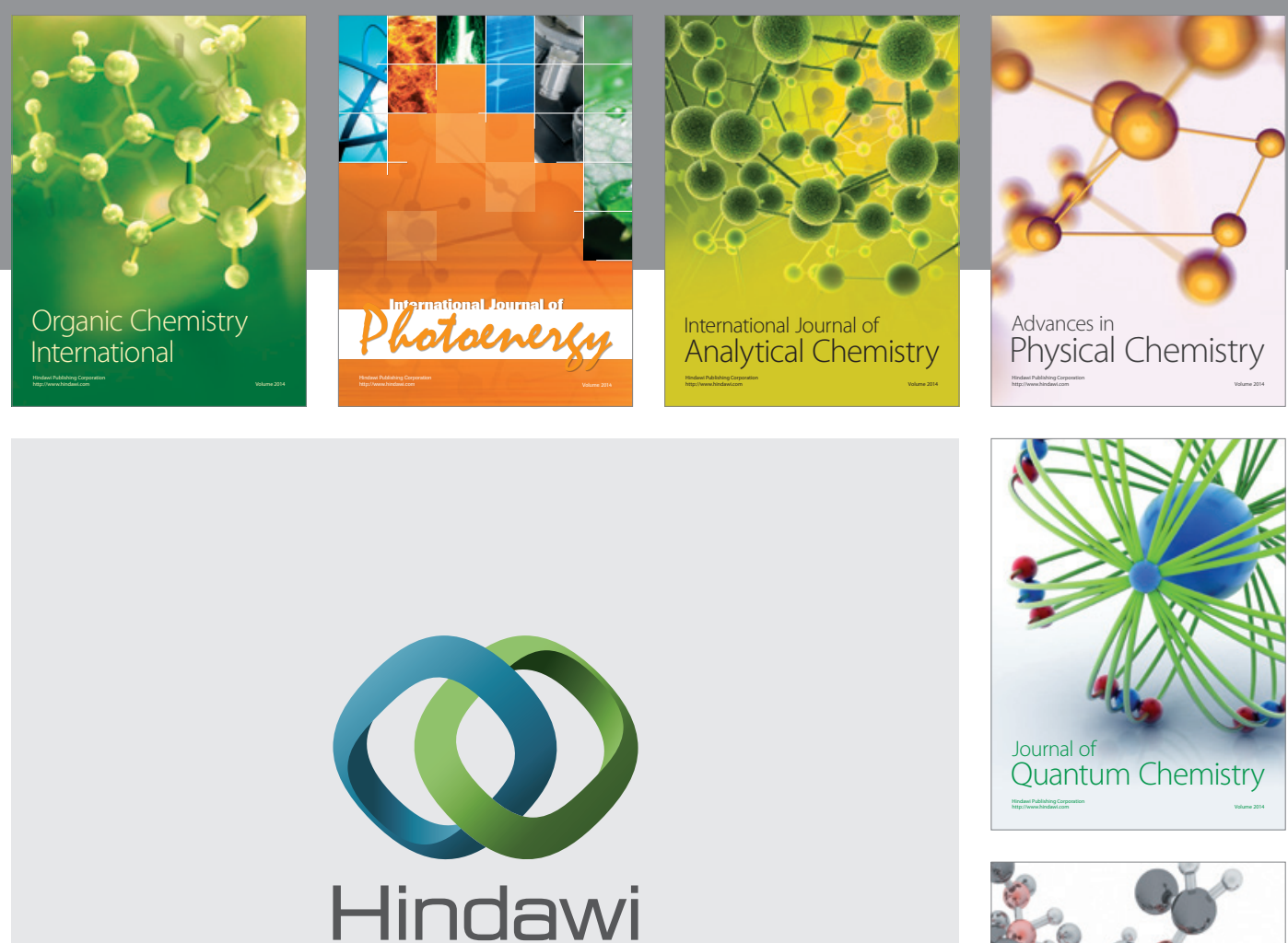

Submit your manuscripts at

http://www.hindawi.com

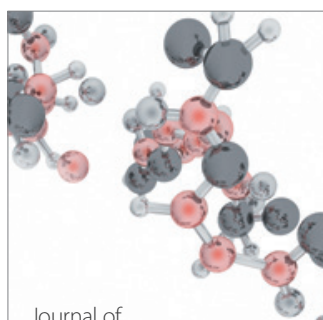

Analytical Methods

in Chemistry

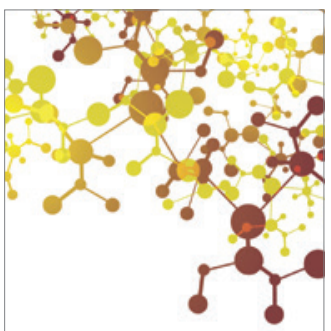

Journal of

Applied Chemistry

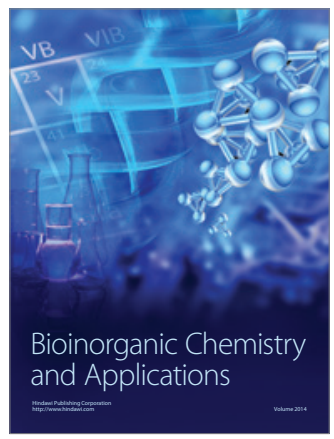

Inorganic Chemistry
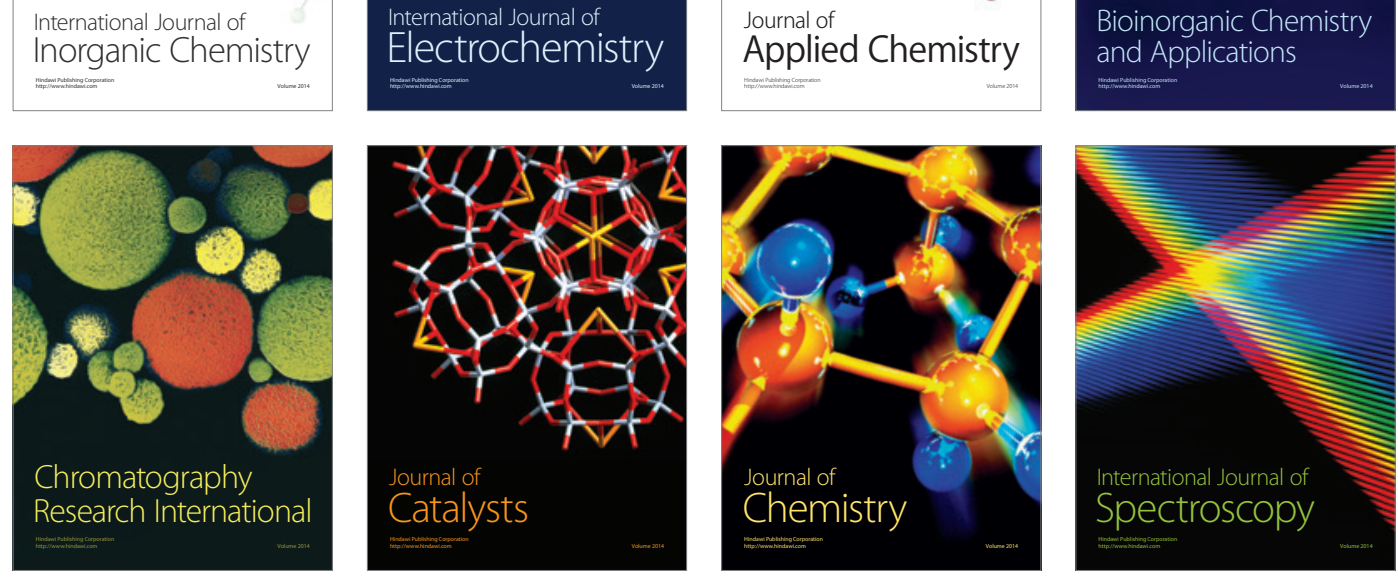